\title{
Influence of players' physique on rugby football injuries
}

\author{
Amanda J Lee, Joanne L Myers, W Michael Garraway
}

\begin{abstract}
Objectives-To determine whether there is an association between a player's physique and injuries incurred while playing rugby football.
\end{abstract}

Methods-A cohort study was carried out involving all senior rugby clubs in the Scottish Borders during the 1993-1994 rugby season. Somatotype estimates were determined for $1152(95 \%)$ of the 1216 eligible players. Body mass index (BMI), chest to waist ratio, and the ponderal index (PI) were used to classify players' physique as endomorphic (obese), mesomorphic (muscular), and ectomorphic (linear).

Results-A strong association was found between physique and age $\left(\chi^{2}\right.$ test: $\chi^{2}=$ 317.2 , df $=10, P<0.0001)$. More younger players were ectomorphs. Older players were more often endomorphic. The physiques of forwards and backs were significantly different $\left(\chi^{2}\right.$ test: $\chi^{2}=58.6$, df $=2$, P<0.0001), with forwards being of a heavier build than three-quarters, even after adjustment for age. Endomorphic players were more likely than ectomorphs to be injured in a match after adjustment for age (age-adjusted mean BMI for players who were injured in a match was 25.4 compared with 24.6 for players who were not injured in a match, $\mathbf{P}<0.0001$; adjusted chest to waist ratio means were 1.136 and 1.125 respectively, $P=0.0307$; adjusted $P I$ means were 0.414 and 0.417 respectively, $P$ $=0.0056$ ). Increased risk of injury may occur when players play out of position, since one fifth of all injuries occurred in this circumstance.

Conclusions-Further research needs to be conducted using a more objective method of measuring somatotype on a further cohort of players so that the risk of injury for different body types can be examined more closely and related to other potential confounding factors. The level of increased risk for individuals playing out of their usual playing position needs to be established with a greater degree of certainty.

(Br F Sports Med 1997;31:135-138)

Keywords: injuries; physique; rugby; somatotype

A J Lee

J L Myers

W M Garraway

Correspondence to: Miss Lee.

Accepted for publication 16 January 1997
Several studies have described injuries in rugby players $^{1-6}$ or have examined the physique of rugby players ${ }^{7-12}$, but only one previous study has looked at the relationship between somato- type and injury in more detail. ${ }^{13}$ Only 28 players of similar age were involved in that study. Another study ${ }^{14}$ looked at factors predisposing to injury in 61 players, but concentrated on players' flexibility, strength, and postural defects, rather than body dimensions. The present study examines the relationship between injury and physique for 1152 players from a representative cohort of senior rugby clubs in the South of Scotland.

\section{Subjects and methods}

The methods used in this survey have already been described. ${ }^{15}$ Players were eligible if they were members of a Scottish Rugby Union affiliated rugby club (South of Scotland District) during the 1993-1994 rugby season. Before the season, 1169 (96\%) of the 1216 eligible players completed a self administered questionnaire detailing personal information, including height, weight, chest, waist, inside leg, collar, and shoe size in terms of the size of clothing worn. The questionnaire was validated on 66 players using a research nurse to physically measure body dimensions after the same players had completed the questionnaire. Players significantly overestimated their chest size (mean (SD) 2.9 (2.2) inches; paired $t$ test, $\mathrm{P}<0.0001)$, underestimated their waist size (mean (SD) 1.5 (1.4) inches, $P<0.0001$ ), overestimated their collar size (mean (SD) 0.37 (0.59) inches, $P<0.0001$ ), and overestimated their inside leg measurement (mean (SD) 0.51 (1.2) inches, $P=0.0017$ ) in the questionnaire. Measurement data for the 1169 players were adjusted accordingly and transformed into metric units before analysis was carried out.

Injury was defined as an injury sustained on the field during a competitive match, during a practice game, or during other training activity directly associated with rugby football, which prevented the player training or playing rugby football from the time of the injury or from the end of the match or practice in which the injury was sustained. Rugby injuries sustained during training were those sustained during practice scrums or manoeuvres involving a rugby ball (not circuit training or activities undertaken to achieve fitness). Rugby injuries were coded according to the International Classification of Diseases (9th revision). ${ }^{16}$ In the cases of multiple injury, the decision on which injury was primarily responsible for incapacity was a matter of clinical judgment.

Somatotyping has been used to classify physique in other studies, ${ }^{713}$ generally using a method devised by Heath and Carter, ${ }^{17}{ }^{18}$ giving a three numeral rating relating to endomorphic (obesity), mesomorphic (muscularity), 


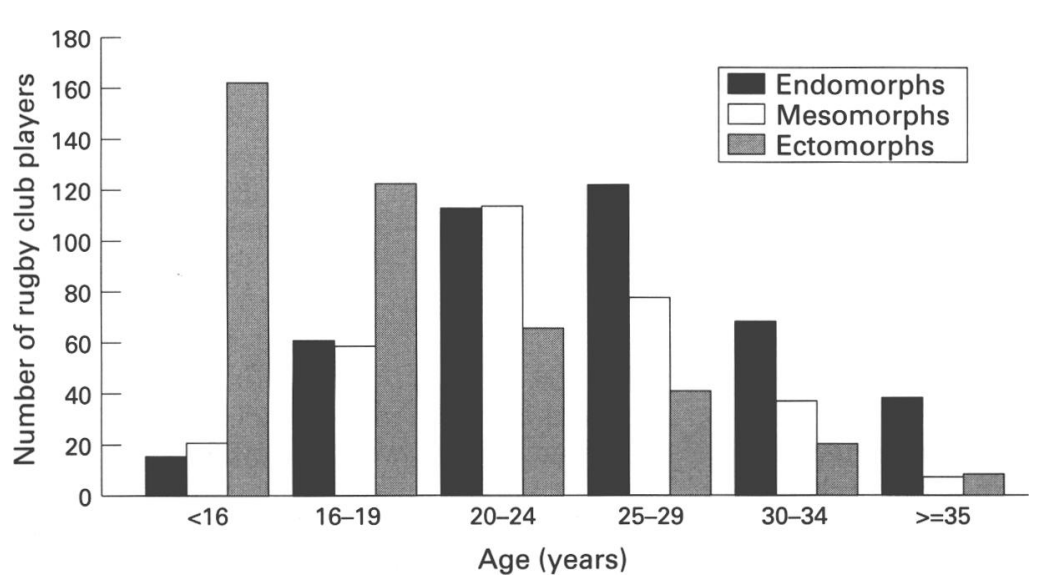

Figure 1 Estimated somatotype distribution by age group.

and ectomorphic (linearity). Physique is then defined as the somatotype with the highest numeral rating. The present study, which involved a large number of players registered with senior rugby clubs scattered throughout a broad geographical area, used an estimate of players' somatotype derived from the Quetelet index or body mass index (BMI), chest to waist ratio, and the ponderal index (PI). ${ }^{19}$ BMI was defined as weight divided by height squared and PI as height divided by the cube root of weight. A total of 1157 players recorded sufficient information to be given a rank (1-1157) for each of these three variables. The variable with the highest ranking was used to determine the estimated somatotype. Five players with equal rankings for BMI and PI were excluded because their estimated somatotype could not be determined. A high BMI denotes an obese player, a high chest to waist ratio denotes a well built muscular player, and a high PI denotes a thin player.

The usual playing position of each player in the rugby team was recorded. This information was not available for 17 of the remaining 1152 players. Players were contacted in the middle and at the end of the season and invited to complete a diary of matches played over the previous three months; these diaries were checked against club fixture lists and the survey's injury register for completeness. Diaries were not available for seven of the 1152 players.

\section{STATISTICAL METHODS}

Match injury status was defined as a binary variable relating to whether a player was injured in a match or not during the seasonthat is, training injuries were ignored. Injuries were classified into 14 clinical categories to define the type of injury sustained. ${ }^{15} \chi^{2}$ test was used to assess the relationship between estimated somatotype and other categorical variables. The BMI, chest to waist ratio, PI, height, and weight means adjusted for-age were obtained from the least squares means estimated from analysis of covariance. Pearson's correlation coefficient was used to assess the relationship between any two variables.

\section{Results}

ESTIMATED SOMATOTYPE

There is a highly significant difference in physique between age groups $\left(\chi^{2}\right.$ test: $\chi^{2}=317.2$, $\mathrm{df}=10, \mathrm{P}<0.0001)$. Younger players were more likely to be tall and thin (ectomorphic), players in their 20s were more muscular (mesomorphic), and the older players were more obese (endomorphic) (fig 1).

Relatively strong relationships existed between age and BMI $(r=0.542, \mathrm{P}<0.0001)$ and the PI $(r=-0.449, \mathrm{P}<0.0001)$, although the relationship between age and chest to waist ratio was only weak $(r=0.184, \mathrm{P}<0.0001)$.

Of the 1152 players with estimated somatotype, the mean (SE) BMI was 24.80 (0.101). BMI ranged from 14.53 for a boy aged 12 years (1.68 $\mathrm{m}$ in height and $41 \mathrm{~kg}$ in weight) to 38.82 for a player aged 25 years $(1.78 \mathrm{~m}$ in height and $123 \mathrm{~kg}$ in weight). The mean (SE) chest to waist ratio was $1.128(0.0022)$. Chest to waist ratio ranged from 0.667 for a player aged 18 years $(63 \mathrm{~cm}$ chest and $95 \mathrm{~cm}$ waist) to 1.390 for a player aged 19 years $(104 \mathrm{~cm}$ chest and 75 cm waist). The mean (SE) PI was 0.417 (0.00053) and ranged from 0.358 to 0.487 , with the same two players at these extremes as for the BMI.

\section{ESTIMATED SOMATOTYPE BY USUAL PLAYING} POSITION

There was a significant difference in physique between forwards and three-quarters $\left(\chi^{2}\right.$ test: $\chi^{2}=58.6, \mathrm{df}=2, \mathrm{P}<0.0001$ ) (table 1). Even when adjusting for age, a significant difference $(P<0.0001)$ was present between forwards and backs for the mean BMI, PI, height, and weight, but not for the mean chest to waist ratio (table 2). Chest, waist, and neck sizes were also significantly $(P<0.0001)$ different between forwards and backs. Of the forwards, props had the largest chest, waist, and neck sizes (means (SE) $102.2(0.6), 91.9(0.4)$, and $40.9(0.2) \mathrm{cm}$ respectively) whereas hookers had the smallest chest, waist, and neck sizes (means (SE) 97.7 (0.9), $86.8(0.6)$, and $39.6(0.3) \mathrm{cm}$ respectively). Of the backs, scrum half players had the smallest chest, waist, and neck sizes (means (SE) $93.2(0.8), 82.9(0.6)$, and $37.9(0.3) \mathrm{cm}$ respectively) whereas full backs had the largest chest and waist sizes (means (SE) 98.0 (0.9) and $86.4(0.6) \mathrm{cm}$ respectively) and centres had the largest neck sizes (mean (SE) 38.9 $(0.2) \mathrm{cm}$ ).

\section{ESTIMATED SOMATOTYPE BY INJURY STATUS}

Of the 1152 players with an estimated somatotype, 354 (31\%) were injured during the 1993-1994 rugby season in 504 injury episodes. Three hundred and eight of these players were injured in matches in 423 injury episodes of which $71(17 \%)$ were recurrent injuries. There was a significant difference in the number of players injured and not injured in matches between physique categories $\left(\chi^{2}\right.$ test: $\left.\chi^{2}=24.4, \mathrm{df}=2, \mathrm{P}<0.0001\right)$. Fewer ectomorphic players were injured in matches than expected (79 $v$ 113), more endomorphic players were injured (140 $v 111)$ with no difference for mesomorphs (89v 84). 
Table 1 Estimated somatotype for each usual playing position

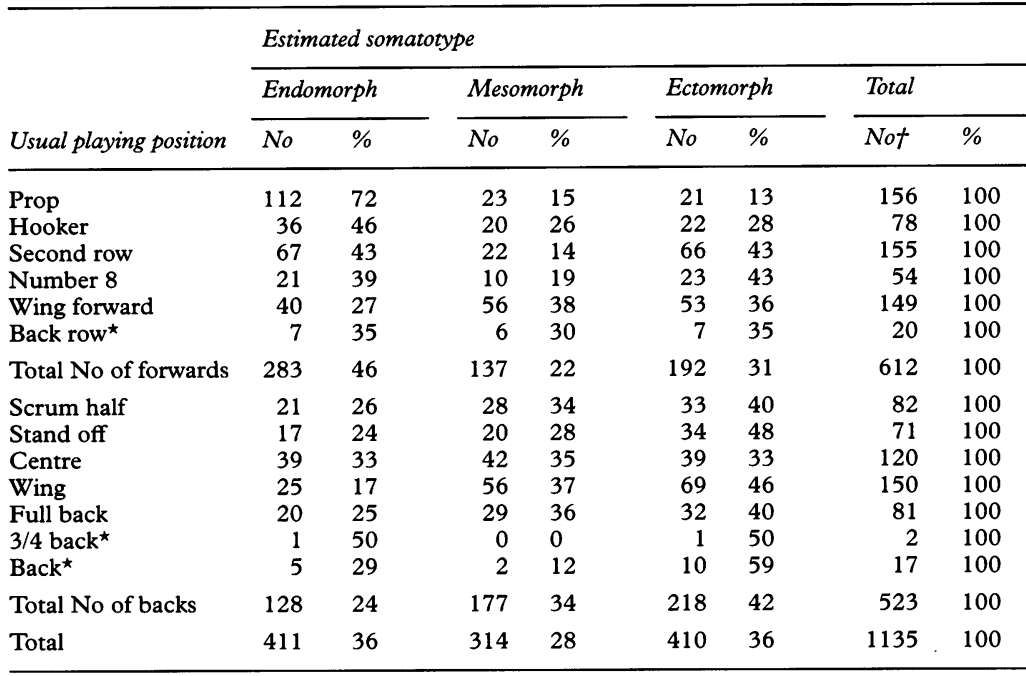

* Players who did not specify an exact position.

$\dagger 17$ players did not specify their usual playing position.

Table 2 Mean (SE) body mass index (BMI), chest to waist ratio, ponderal index (PI), height, and weight for each usual playing position. All values are adjusted for age

\begin{tabular}{|c|c|c|c|c|c|c|}
\hline $\begin{array}{l}\text { Usual playing } \\
\text { position }\end{array}$ & Not & $B M I$ & $\begin{array}{l}\text { Chest to waist } \\
\text { ratio }\end{array}$ & $P I$ & Height & Weight \\
\hline Prop & 156 & $\begin{array}{l}27.96 \\
(0.203)\end{array}$ & $\begin{array}{l}1.112 \\
(0.0059)\end{array}$ & $\begin{array}{l}0.400 \\
(0.0011)\end{array}$ & $\begin{array}{l}1.759 \\
(0.006)\end{array}$ & $\begin{array}{l}87.03 \\
(0.88)\end{array}$ \\
\hline Hooker & 78 & $\begin{array}{l}25.53 \\
(0.286)\end{array}$ & $\begin{array}{l}1.126 \\
(0.0084)\end{array}$ & $\begin{array}{l}0.409 \\
(0.0016)\end{array}$ & $\begin{array}{l}1.733 \\
(0.009)\end{array}$ & $\begin{array}{l}77.12 \\
(1.24)\end{array}$ \\
\hline Second row & 155 & $\begin{array}{l}25.05 \\
(0.203)\end{array}$ & $\begin{array}{l}1.119 \\
(0.0060)\end{array}$ & $\begin{array}{l}0.421 \\
(0.0011)\end{array}$ & $\begin{array}{l}1.852 \\
(0.006)\end{array}$ & $\begin{array}{l}86.73 \\
(0.88)\end{array}$ \\
\hline Number 8 & 54 & $\begin{array}{l}25.30 \\
(0.343)\end{array}$ & $\begin{array}{l}1.132 \\
(0.0101)\end{array}$ & $\begin{array}{l}0.418 \\
(0.0019)\end{array}$ & $\begin{array}{l}1.829 \\
(0.011)\end{array}$ & $\begin{array}{l}85.07 \\
(1.49)\end{array}$ \\
\hline Wing forward & 149 & $\begin{array}{l}24.46 \\
(0.206)\end{array}$ & $\begin{array}{l}1.145 \\
(0.0061)\end{array}$ & $\begin{array}{l}0.419 \\
(0.0012)\end{array}$ & $\begin{array}{l}1.788 \\
(0.006)\end{array}$ & $\begin{array}{l}78.56 \\
(0.90)\end{array}$ \\
\hline Back row* & 20 & $\begin{array}{l}24.29 \\
(0.565)\end{array}$ & $\begin{array}{l}1.123 \\
(0.0166)\end{array}$ & $\begin{array}{l}0.423 \\
(0.0032)\end{array}$ & $\begin{array}{l}1.823 \\
(0.018)\end{array}$ & $\begin{array}{l}81.10 \\
(2.45)\end{array}$ \\
\hline $\begin{array}{l}\text { Total No of } \\
\text { forwards }\end{array}$ & 612 & $\begin{array}{l}25.70 \\
(0.110)\end{array}$ & $\begin{array}{l}1.126 \\
(0.0030)\end{array}$ & $\begin{array}{l}0.413 \\
(0.0006)\end{array}$ & $\begin{array}{l}1.795 \\
(0.004)\end{array}$ & $\begin{array}{l}83.24 \\
(0.46)\end{array}$ \\
\hline Scrum half & 82 & $\begin{array}{l}23.59 \\
(0.278)\end{array}$ & $\begin{array}{l}1.124 \\
(0.0082)\end{array}$ & $\begin{array}{l}0.416 \\
(0.0016)\end{array}$ & $\begin{array}{l}1.688 \\
(0.009)\end{array}$ & $\begin{array}{l}68.00 \\
(1.21)\end{array}$ \\
\hline Stand off & 71 & $\begin{array}{l}23.64 \\
(0.300)\end{array}$ & $\begin{array}{l}1.128 \\
(0.0088)\end{array}$ & $\begin{array}{l}0.421 \\
(0.0017)\end{array}$ & $\begin{array}{l}1.745 \\
(0.009)\end{array}$ & $\begin{array}{l}72.53 \\
(1.30)\end{array}$ \\
\hline Centre & 120 & $\begin{array}{l}24.22 \\
(0.230)\end{array}$ & $\begin{array}{l}1.134 \\
(0.0068)\end{array}$ & $\begin{array}{l}0.418 \\
(0.0013)\end{array}$ & $\begin{array}{l}1.757 \\
(0.007)\end{array}$ & $\begin{array}{l}75.27 \\
(1.00)\end{array}$ \\
\hline Wing & 150 & $\begin{array}{l}23.65 \\
(0.206)\end{array}$ & $\begin{array}{l}1.132 \\
(0.0061)\end{array}$ & $\begin{array}{l}0.422 \\
(0.0012)\end{array}$ & $\begin{array}{l}1.761 \\
(0.006)\end{array}$ & $\begin{array}{l}73.73 \\
(0.90)\end{array}$ \\
\hline Full back & 81 & $\begin{array}{l}23.87 \\
(0.280)\end{array}$ & $\begin{array}{l}1.134 \\
(0.0082)\end{array}$ & $\begin{array}{l}0.421 \\
(0.0016)\end{array}$ & $\begin{array}{l}1.768 \\
(0.009)\end{array}$ & $\begin{array}{l}75.01 \\
(1.22)\end{array}$ \\
\hline $3 / 4$ back $^{\star}$ & 2 & $\begin{array}{l}21.96 \\
(1.785)\end{array}$ & $\begin{array}{l}1.079 \\
(0.0524)\end{array}$ & $\begin{array}{l}0.431 \\
(0.0101)\end{array}$ & $\begin{array}{l}1.751 \\
(0.056)\end{array}$ & $\begin{array}{l}67.69 \\
(7.75)\end{array}$ \\
\hline Back* & 17 & $\begin{array}{l}23.56 \\
(0.612)\end{array}$ & $\begin{array}{l}1.129 \\
(0.0180)\end{array}$ & $\begin{array}{l}0.427 \\
(0.0035)\end{array}$ & $\begin{array}{l}1.826 \\
(0.019)\end{array}$ & $\begin{array}{l}78.84 \\
(2.65)\end{array}$ \\
\hline $\begin{array}{l}\text { Total No of } \\
\text { backs }\end{array}$ & 523 & $\begin{array}{l}23.80 \\
(0.119)\end{array}$ & $\begin{array}{l}1.130 \\
(0.0033)\end{array}$ & $\begin{array}{l}0.420 \\
(0.0007)\end{array}$ & $\begin{array}{l}1.750 \\
(0.004)\end{array}$ & $\begin{array}{l}73.39 \\
(0.50)\end{array}$ \\
\hline Total & 1135 & $\begin{array}{l}24.82 \\
(0.003)\end{array}$ & $\begin{array}{l}1.128 \\
(0.0001)\end{array}$ & $\begin{array}{l}0.416 \\
(0.0000)\end{array}$ & $\begin{array}{l}1.774 \\
(0.000)\end{array}$ & $\begin{array}{l}78.70 \\
(0.01)\end{array}$ \\
\hline
\end{tabular}

$\star$ Players who did not specify an exact position.

$\dagger 17$ players did not specify their usual playing position.

Match injury status was associated with age $\left(\chi^{2}\right.$ test: $\left.\chi^{2}=49.5, \mathrm{df}=5, \mathrm{P}<0.0001\right)$, with more players injured in matches than expected for those aged 20-34 years old. There was no increased risk from playing more matches, indeed those who were injured played significantly fewer $(t$ test, $\mathrm{P}<0.0001)$ matches during the season (mean (SE) $17.8(0.51)$ ) than those who were not injured $(20.6(0.40))$. This effect was not significant after adjustment for age. No association between match injury status and usual playing position was observed $\left(\chi^{2}\right.$ test: $\chi^{2}$ $=8.2, \mathrm{df}=9, \mathrm{P}=0.51)$. After adjustment for age, there was a significant difference $(\mathrm{P}<0.0001)$ in the BMI between players
Table 3 Match injury episodes occurring while player were playing in and out of their usual playing position

\begin{tabular}{|c|c|c|c|c|c|c|}
\hline \multirow[b]{2}{*}{$\begin{array}{l}\text { Usual } \\
\text { playing } \\
\text { position }\end{array}$} & \multirow[b]{2}{*}{ Not } & \multirow[b]{2}{*}{$\begin{array}{l}\text { Players } \\
\text { not } \\
\text { injured }\end{array}$} & \multicolumn{2}{|c|}{$\begin{array}{l}\text { Injured in } \\
\text { positon }\end{array}$} & \multicolumn{2}{|c|}{$\begin{array}{l}\text { Injured out of } \\
\text { position }\end{array}$} \\
\hline & & & Players & $\begin{array}{l}\text { New + } \\
\text { old } \\
\text { episodes }\end{array}$ & Playe & $\begin{array}{l}\text { New + } \\
\text { old } \\
\text { s episodes }\end{array}$ \\
\hline Prop & 156 & 120 & 33 & $34+14$ & 5 & $4+1$ \\
\hline Hooker & 78 & 57 & 16 & $17+4$ & 5 & $4+1$ \\
\hline Second row & 155 & 114 & 35 & $39+5$ & 7 & $7+4$ \\
\hline Number 8 & 54 & 33 & 16 & $21+4$ & 7 & $6+2$ \\
\hline Wing & & & & & & \\
\hline forward & 149 & 103 & 35 & $37+5$ & 15 & $16+5$ \\
\hline Back row^ & 20 & 12 & 7 & $10+1$ & 2 & $2+0$ \\
\hline $\begin{array}{c}\text { Total No of } \\
\text { forwards }\end{array}$ & 612 & 439 & 142 & $158+33$ & 41 & $39+13$ \\
\hline Scrum half & 82 & 63 & 18 & $23+1$ & 1 & $1+0$ \\
\hline Stand off & 71 & 52 & 17 & $23+3$ & 4 & $4+0$ \\
\hline Centre & 120 & 88 & 25 & $24+9$ & 9 & $9+2$ \\
\hline Wing & 150 & 115 & 28 & $28+3$ & 8 & $7+1$ \\
\hline Full back & 81 & 57 & 20 & $22+5$ & 5 & $6+1$ \\
\hline $3 / 4$ back $^{\star}$ & 2 & 0 & 2 & $2+0$ & 0 & $0+0$ \\
\hline Back $^{\star}$ & 17 & 14 & 2 & $2+0$ & 1 & $3+0$ \\
\hline $\begin{array}{l}\text { Total No of } \\
\text { backs }\end{array}$ & 523 & 389 & 112 & $124+21$ & 28 & $30+4$ \\
\hline Total & 1135 & 828 & 254 & $282+54$ & 69 & $69+17$ \\
\hline
\end{tabular}

* Players who did not specify an exact position.

+17 players did not specify their usual playing position.

Note: Number of players does not add up to total as 16 players were injured at least once in position and at least once out of position.

injured in matches (mean (SE) 25.4 (0.164)) and players not injured in matches (24.6 $(0.099)$ ), in the chest to waist ratio (means (SE) $1.136(0.0042)$ and $1.125 \quad(0.0026)$ respectively, $P=0.0307$ ), and in the PI (means (SE) $0.414(0.0009)$ and $0.417(0.0006)$ respectively, $P=0.0056$ ).

No significant difference was observed between physique and the phase of play in which the injury occurred for those playing in the forwards at the time of injury $\left(\chi^{2}\right.$ test: $\chi^{2}=14.4, \mathrm{df}$ $=14, \mathrm{P}=0.42$ ) or those playing three-quarters at the time of injury ( $\chi^{2}$ test excluding scrum, maul and lineout: $\chi^{2}=6.3, \mathrm{df}=8, \mathrm{P}=0.61$ ).

One fifth of all injury episodes occurred whilst a player was playing out of his usual playing position (table 3 ), with little difference between estimated somatotypes: endomorphs, $19 \%$; mesomorphs, $21 \%$; and ectomorphs, $22 \%$. Wing forwards incurred the highest proportion of injury episodes while playing out of position (33\%), followed by centres $(25 \%)$ and number 8 players $(24 \%)$.

ESTIMATED SOMATOTYPE BY TYPE OF INJURY After adjustment for age and usual playing position (forward or back), the mean BMI was significantly higher for those 36 players with shoulder dislocations, strains, and sprains occurring in matches compared with the 1099 players without such injuries (means (SE) 25.8 (0.45) and $24.8(0.08)$ respectively, $\mathrm{P}=$ 0.0214 ), for those 35 players with hip or thigh dislocations, strains, and sprains (means (SE) $25.9(0.46)$ and $24.8(0.08)$ respectively, $\mathrm{P}=$ 0.0129 ), for those 22 players with lower limb lacerations and contusions (means (SE) 26.1 (0.58) and $24.8(0.08)$ respectively, $\mathrm{P}=$ $0.0226)$, and for those 38 players with back strains and sprains (means (SE) $26.3(0.44)$ and $24.8(0.08)$ respectively, $\mathrm{P}=0.0004)$. The 
mean PI adjusted for age and usual playing position was significantly lower for those with back strains and sprains compared with those without such injuries (means (SE) 0.410 $(0.0025)$ and $0.417(0.0005)$ respectively, $P=$ 0.0078).

\section{Discussion}

This is the first study to assess the influence of players' body size on injury in such a large representative cohort of rugby players.

There is a great variety in players' physique by different playing positions. The laws of the game encourage different playing requirements for forwards and backs. Forwards need power and weight to provide a strong pushing force in the scrum and maul, and height to compete in the lineouts. Backs need to be fast and agile to clear the ball away from the scrum and advance it down the pitch or defend against the intrusion of opposing three-quarters. As expected, there were noticeable differences in physique within forwards and backs, with prop forwards being the largest and heaviest forwards and scrum half players being the smallest and lightest backs. Other studies have found similar results. ${ }^{7-12}$

It has previously been suggested that muscular players are cushioned in collisions ${ }^{13}$ and that the incidence of injury may be associated with underdeveloped muscles. ${ }^{14}$ Endomorphs have been found to have the highest injury rate in this survey. The increased absolute risk of injury to heavier players may be due to variations in exposure to different phases of play. However, the relative risk of injury in each phase of play cannot be determined for each playing position because we do not know how many times each playing position is involved in different phases of play. These may vary markedly according to level of skill and weather and pitch conditions. The difference in absolute risk of injury between ectomorphic and endomorphic players may be associated with the way in which they play rugby. It is also possible that estimated somatotype is confounding with other risk factors not considered in this survey-for example, particular personality traits, different levels of motor skills, different levels of physical fitness. Furthermore, ectomorphic players may be more likely to play for weaker teams and as a result have a lower risk of injury. ${ }^{21}$ This cannot be excluded from our survey.

It is possible that somatotype may be a more important risk factor in schoolboy rugby than senior club rugby. All analyses have been adjusted for age, but this would not allow for the different physical maturation rates in schoolboys in their mid to late teens.

A more objective somatotyping method would have allowed a more accurate representation of each player's physique. However, this would have been very time consuming and costly to achieve in such a large cohort spread over a wide geographical area. The methods used in this study allow a broad picture of physique to be assessed, although BMI could reflect muscularity rather than obesity, particularly in rugby players.
There may be an increased risk of injury for players playing out of their usual playing position. The lowest injury rates occurred in playing positions in which players rarely play out of position. For example, few injury episodes occurred out of position for scrum half players (4\%) and props (9\%). This may be because these positions require more specific skills and the players are less likely to play in another position. The actual risk of injury for players playing out of position cannot be determined because there are no data on how many times a player played out of position during the season. Further research needs to be conducted to establish with a greater degree of certainty the level of increased risk for individuals playing out of their usual playing position. If such an increased risk exists it has important implications for those who select and train players.

We thank the following: George Murray, district secretary for the South of Scotland; the presidents and linkmen of participating clubs; Donald Macleod, honorary medical advisor, SRU, Gregor Nicholson, administrative secretary, SRU; Sue Hutton, our survey coordinator; the chartered physiotherapists of the our survey coordinator; the chartered physiotherapists of the Fitness Assessment and Sports Injuries Centre, University of Edinburgh Department of Physical Education; Lyn Chalmers for computing support; Robin Prescott for statistical advice;
Anne Simmons and Caroline Adams for secretarial services; Anne Simmons and Caroline Adams for secretarial services;
and, finally, the players of the Scottish Borders for their outstanding cooperation.

1 O'Brien C. Retrospective survey of rugby injuries in the Leinster province of Ireland 1987-1989. Br 7 Sports Med 1992;26:243-4.

2 Clark DR, Roux C, Noakes TD. A prospective study of the incidence and nature of injuries in adult rugby players. $S$ Afr Med F 1990;77:559-62.

3 Seward H, Orchard J, Hazard H, Collinson D. Football injuries in Australia at the élite level. Med $\mathcal{F}$ Aust 1993;159. 298-301.

4 Addley K, Farren J. Irish rugby injury survey: Dungannon football club (1986-1987). Br ₹ Sports Med 1988;22:22-4.

5 Myers PT. Injuries presenting from rugby union football. Med $\mathcal{F}$ Aust 1980;2:17-20.

6 Davies JE, Gibson T. Injuries in rugby union football. $B M \mathcal{F}$ 1978;2:1759-61.

7 Casagrande G, Viviani F. Somatotype of Italian rugby players. F Sports Med Phys Fitness 1993;33:65-9.

8 Quarrie KL, Handcock P, Waller AE, Chalmers DJ, Toomey MJ, Wilson BD. The New Zealand Rugby Injury and Performance Project. III. Anthropometric and physical performance characteristics of players. $\mathrm{Br} \mathcal{F}$ Sports Med 1995;29:263-70.

9 Quarrie KL, Handcock P, Toomey MJ, Waller AE. The New Zealand Rugby Injury and Performance Project. IV. Anthropometric and physical performance comparisons between positional categories of senior A rugby players. $B$ $f$ Sports Med $1996 ; 30: 53-6$
.

10 Maud PJ. Physiological and anthropometric parameters that describe a rugby union team. Br $f$ Sports Med 1983;17:1623.

11 Bell W. Body composition of rugby union football players. Br F Sports Med 1979;13:19-23.

12 Carlson BR, Carter JEL, Patterson P, Petti K, Orfanos SM Noffal GJ. Physique and motor performance characteristic of US national rugby players. F Sports Sci 1994;12:403-12.

13 Reilly T, Hardiker R. Somatotype and injuries in adult student rugby football. $\mathcal{f}$ Sports Med 1981;21:186-91.

14 Watson AWS. Factors predisposing to sports injury in school boy rugby players. I Sports Med 1981;21:417-22

15 Garraway WM, Macleod DAD. Epidemiology of rugby football injuries. Lancet 1995;345:1485-7.

16 International classification of disease (9th revision). Manua of the international statistical classification of diseases, injuries and causes of death. WHO, Geneva. London, HMSO, 1977.

17 Heath BH, Carter JEL. A modified somatotype method. Am f Phys Anthropol 1967;27:57-74.

18 Carter JEL, Heath BH. Somatoyping: development and applications. Cambridge: Cambridge University Press, 1989.

19 Sheldon WH, Stevens SS, Tucker WB. The varieties human physique: an introduction to constitutional psychology. New York and London: Harper, 1940.

20 Parnell PW. Behaviour and physique: an introduction to practical applied somatometry. London: Arnold, 1958.

21 Upton PAH, Roux CE, Noakes TD. Inadequate pre-season preparation of schoolboy rugby players: a survey of players preparation of schoolboy rugby players: a survey of players
at 25 Cape Province high schools. S Afr Med $\mathfrak{f}$ 1996;86:531-3. 